\title{
Distribution of cockles Cerastoderma edule in the Eastern Scheldt: habitat mapping with abiotic variables
}

\author{
B. J. Kater ${ }^{1,2, *}$, A. J. M. Geurts van Kessel $^{2}$, J. J. M. D. Baars ${ }^{1}$ \\ ${ }^{1}$ Netherlands Institute for Fisheries Research-Centre for Shellfish Research, PO Box 77, 4400 AB Yerseke, The Netherlands \\ ${ }^{2}$ Netherlands Institute for Coastal and Marine Management, PO Box 8039, 4330 EA Middelburg, The Netherlands
}

\begin{abstract}
On the basis of maps of environmental variables and annual surveys, a habitat map was constructed for the cockle Cerastoderma edule, a commercially exploited dominant suspension feeder in the Eastern Scheldt (The Netherlands). The results obtained show that the distribution of cockles can be described using emersion time and current velocity. Salinity does not play a significant role, even though low salinities are known to limit the distribution of cockles in other areas. The response to current velocity was as expected, but the response to emersion contradicted results from other studies. These responses cannot be explained as the result of competition for space with the recently expanded Pacific oyster population, because Pacific oysters are most common in habitats that are unsuitable for cockles. Possible explanations for cockles' apparent preference for settling in areas with relatively long emersion times are high predation pressure or instability of the sediment around low water level.
\end{abstract}

KEY WORDS: Cerastoderma edule $\cdot$ Habitat map $\cdot$ Eastern Scheldt

\section{INTRODUCTION}

Alongside the blue mussel Mytilus edulis and the Pacific oyster Crassostrea gigas, another dominant suspension feeder in the Eastern Scheldt (The Netherlands) is the cockle Cerastoderma edule. Cockles are abundant on most intertidal flats, and densities are generally high, though they vary from year to year depending on the success of spat fall and on mortality (Coosen et al. 1994). Because of their high abundance, cockles are commercially exploited in the Eastern Scheldt (Dijkema 1997). This has led to conflict with conservationists, especially when suction dredges are used in areas of major ecological value, like the Eastern Scheldt. In 1993 the government of The Netherlands implemented a policy to ensure the protection of natural values in such areas, while allowing restricted human activities. Under this policy, cockle fishing is allowed in the Eastern Scheldt, provided that there are no negative effects on cockle stocks (Kamermans \& Smaal 2002). It is known that cockles and cockle stocks are affected by cockle fishing (Piersma et al. 2001, Ens 2003). A major research programme was initiated to evaluate the effect of shellfish fisheries on the natural levels in the Wadden Sea and Eastern Scheldt (Ens et al. 2004). The present study is part of that programme.

Cockle distribution is influenced by abiotic variables including current velocity, emersion time, salinity and sediment composition, by biotic variables including other species and predation, and by human exploitation. Current velocity can have an effect on both settlement of larvae and growth of bivalves. Cockles start their lives as larvae in the water column. After a few weeks they settle to the sediment (spat fall). Current velocity is an important variable in the transition of larvae from the water column to the sediment. Current velocities also have an impact on food availability, which affects cockle growth rates. Reports concerning 
the effects of increasing flow velocity on bivalve growth rates have been contradictory. Some studies have reported increased growth rates with increased flow velocity. This could be attributed to increased food supplies or feeding efficiency (Wildish \& Kristmanson 1985, Eckman 1987). In contrast, other studies have reported that growth rates tend to decrease with increased flow velocity (Wildish et al. 1987, Eckman et al. 1989, Wildish \& Saulnier 1992).

In addition to current velocity, emersion time plays an important role in defining cockle habitats. It is commonly accepted that food supply is mainly linked to duration of emersion. Another potential factor limiting habitat is salinity. In the Baltic Sea cockles are found at salinities of $10 \%$ and higher (Brock 1980). Larvae prefer salinities between 30 and $35 \%$, but can survive at salinities as low as 5\%o (Kingston 1974). Ysebaert et al. (2002) modelled the Western Scheldt cockle population and predicted cockles would thrive at salinities between 10 and $30 \%$, with the optimum at $25 \%$.

One abiotic variable known to influence the distribution of cockles is the composition of the sediment. However, we were unable to investigate this variable due to lack of data.

The Pacific oyster Crassostrea gigas was imported to the Eastern Scheldt in 1964 for culturing purposes (Dijkema 1997). In 1976 and 1982 larval outbursts established wild Pacific oysters in the waters of the Eastern Scheldt (Drinkwaard 1999), and since that time oyster beds in intertidal and subtidal areas have expanded. One of the main problems in the Eastern Scheldt associated with the expansion of Pacific oysters is the potential for negative impact on commercially exploited indigenous species. Wild Pacific oysters can compete for food and space with commercial species like cockles and mussels (Smaal et al. 2001).

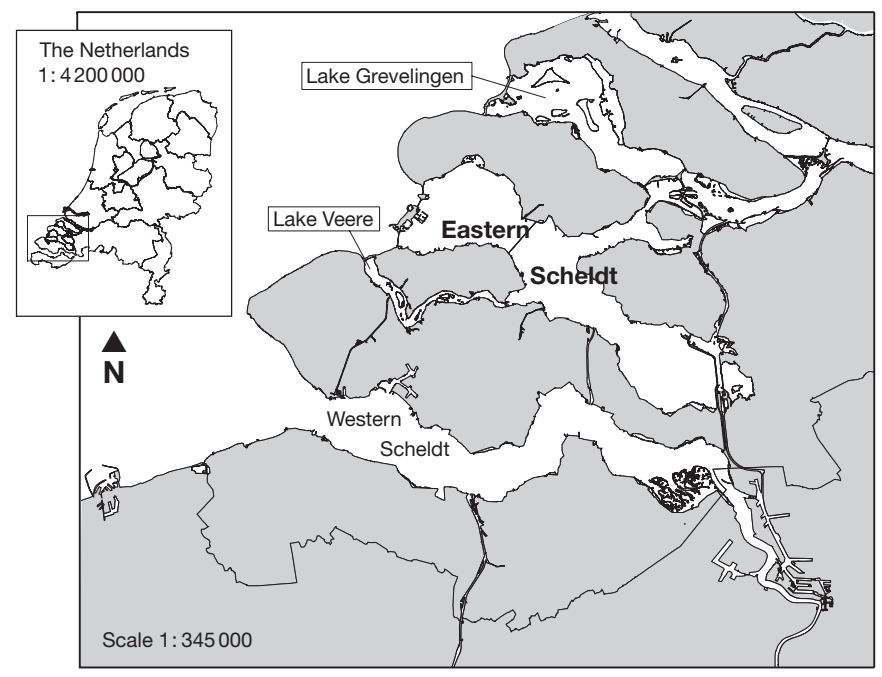

Fig. 1. Map showing location of the Eastern Scheldt estuary
The objectives of this study were to describe the distribution of cockles in the Eastern Scheldt by creating a habitat map using several abiotic variables, and to discuss this distribution, including the potential influence of Pacific oysters.

\section{MATERIALS AND METHODS}

Study area and data. This study was performed on intertidal areas in the Eastern Scheldt, The Netherlands (Fig. 1), Cockles have been surveyed annually on the Eastern Scheldt intertidal areas since 1990. Our surveys were performed in spring at approx. 500 sampling stations, lying on north-south vectors. The distance between sampling points was 0.25 geographical minutes $(\approx 460 \mathrm{~m})$, while the distance between vectors was 0.5 geographical minutes $(\approx 555 \mathrm{~m})$. Samples were taken with a special cocklesampling device, which has a sample surface of $0.1 \mathrm{~m}^{2}$. Samples were collected using a $2 \mathrm{~mm}$ mesh sieve, and the cockles in each sample were counted and wet-weighed. The number and wet-weight biomass of cockles $\mathrm{m}^{-2}$ were calculated from these data. The biomass measurements for each sampling station from1990 to 2001 were averaged and used for modelling purposes.

Three datasets of environmental parameters, organised as maps, were used to explain the distribution of cockle biomass in the Eastern Scheldt: emersion time $(20 \times 20 \mathrm{~m}$ grid) , current velocities at ebb during spring tide $(50 \times 50 \mathrm{~m}$ grid $)$ and salinity $(100 \times 100 \mathrm{~m}$ grid $)$. Emersion times were based on depths and water levels measured between 1990 and 1994, and varied between 0 and $93 \%$. Current velocities and salinity were calculated using a current velocity model and a salinity model for the Eastern Scheldt. Current velocities varied between 4 and $74 \mathrm{~cm} \mathrm{~s}^{-1}$ and salinity between 28 and $33 \%$.

All environmental maps dated to 1994, and were encoded into a GIS (ArcView v3.2), together with the cockle sample points. Emersion time, current velocity and salinity were linked to each cockle sample point using Getgridvalue (Davies 2000).

Habitat modelling and mapping. A stepwise backward generalized linear model was fitted using a Poisson distribution and log link function, using SAS software. The model can be expressed as:

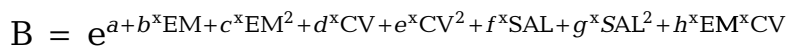

$$
\begin{aligned}
& +i^{\mathrm{x}} \mathrm{EM}^{\mathrm{x}} \mathrm{SAL}+j^{\mathrm{x}} \mathrm{CV}^{\mathrm{x}} \mathrm{SAL}+k^{\mathrm{x}} \mathrm{EM}^{\mathrm{x}} C V^{\mathrm{x}} \mathrm{SAL}
\end{aligned}
$$

where B is biomass of cockles, EM is emersion time, $\mathrm{CV}$ is current velocity, SAL is salinity, and $a$ to $k$ are parameters to be estimated. Terms were removed when $\mathrm{p}>0.01$. 
To create the habitat map, a grid of $100 \times 100 \mathrm{~m}$ was made in the GIS using the script Create Map Grid Theme (Banerjee 2000) and overlaid onto the Eastern Scheldt map. The environmental information for each grid cell was derived from the environmental maps, and cockle biomass was estimated for each grid cell using the habitat model. Cockle habitats can be visualised using this grid by giving high biomass and low biomass cells different colours. To achieve this, cockle biomasses were sorted from high to low and divided into 5 cockle 'suitability' groups with an equal number of grid cells, i.e. $20 \%$ of the total number of grid cells. The following groups were defined: 'very suitable' areas (highest biomass), 'suitable' areas, 'less suitable' areas, 'marginally suitable' areas, 'least suitable' areas (lowest biomass). The total cockle stock in the Eastern Scheldt was estimated using the estimated biomass and surface area of each grid cell.

Relative distribution of cockles and oysters. The intertidal cockle habitat map can be used to study areas colonised by Pacific oysters, in terms of their suitability to cockles. Comparing intertidal Pacific oyster beds in the Eastern Scheldt and the cockle habitat map determines whether Pacific oysters tend to grow in the 'very suitable' or 'less suitable' cockle habitats. Maps of intertidal Pacific oyster beds in 1990 and 2002 (Kater \& Baars 2004) were overlaid onto the cockle habitat map. All grid cells within these polygons were scored, and for each suitability class the number of grids cells within an oyster bed was expressed as a percentage of the total number of grid cells in each class. Differences between years were tested with a $\chi^{2}$ test for independence.

\section{RESULTS}

\section{Habitat modelling}

The analysis, utilising generalized linear modelling, showed that the biomass of cockles could be explained using emersion time (first and second order) and current velocities (first and second order). Salinity and all interaction terms were not significant. Table 1 gives an overview of estimates and p-values for significant parameters. This model explained $37.3 \%$ of the deviance. There was no correlation between emersion time and current velocities. The relationship between emersion time, current velocity and estimated biomass is shown in Fig. 2. The contour plots show that in the Eastern Scheldt the highest cockle biomasses are estimated at intertidal flats with a current velocity range of 27 to $37 \mathrm{~cm} \mathrm{~s}^{-1}$, which emerged for 42 to $57 \%$ of the time.

The cockle biomass for each grid cell in the Eastern Scheldt was estimated using the parameters in Table 1,
Table 1. Significant parameters in the regression analysis (distribution: Poisson; link: log)

\begin{tabular}{|lrl|}
\hline Parameter & Estimate & $\mathrm{p}$-value \\
\hline Emersion time (first order) & 0.11 & $<0.0001$ \\
Emersion time (second order) & -0.0011 & $<0.0001$ \\
Current velocity (first order) & 0.15 & $<0.0001$ \\
Current velocity (second order) & -0.0023 & $<0.0001$ \\
\hline
\end{tabular}

and data from the maps on current velocities and emersion times. Grid cells were shaded according to their biomass (Fig. 3). The habitat map shows 'very suitable' cockle areas on large tidal flats (Roggenplaat, Vondelingsplaat and Slikken van den Dortsman). 'Less suitable' areas are mostly found in the northeastern and southeastern part of the Eastern Scheldt. The average cockle stock in the period 1990 to 2001, used for modelling, was 26.5 million $\mathrm{kg}$ fresh weight. The total stock estimated by the habitat model was 26.8 million $\mathrm{kg}$ fresh weight.

\section{Competition between cockles and oysters}

Using the oyster map of 1990, the highest percentage of Pacific oysters was found in areas classified as 'marginally suitable' for cockles $(8.1 \%)$. Of the grid cells classified as 'very suitable' or 'suitable' for cockles, fewer than $4 \%$ were occupied by Pacific oysters. Using

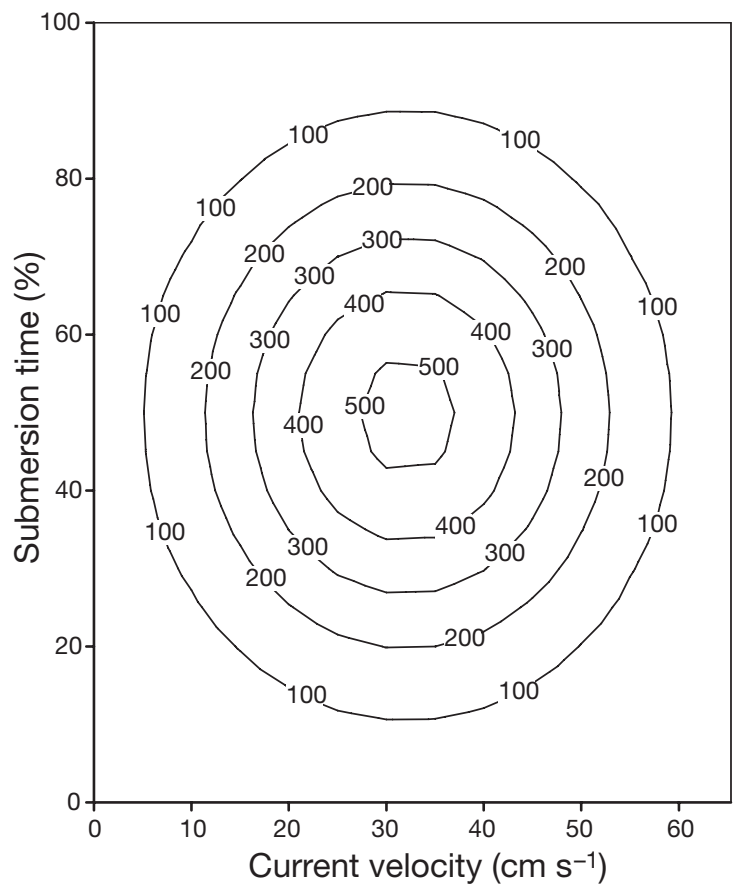

Fig. 2. Contour plot for cockle biomass for given submersion times and current velocities 


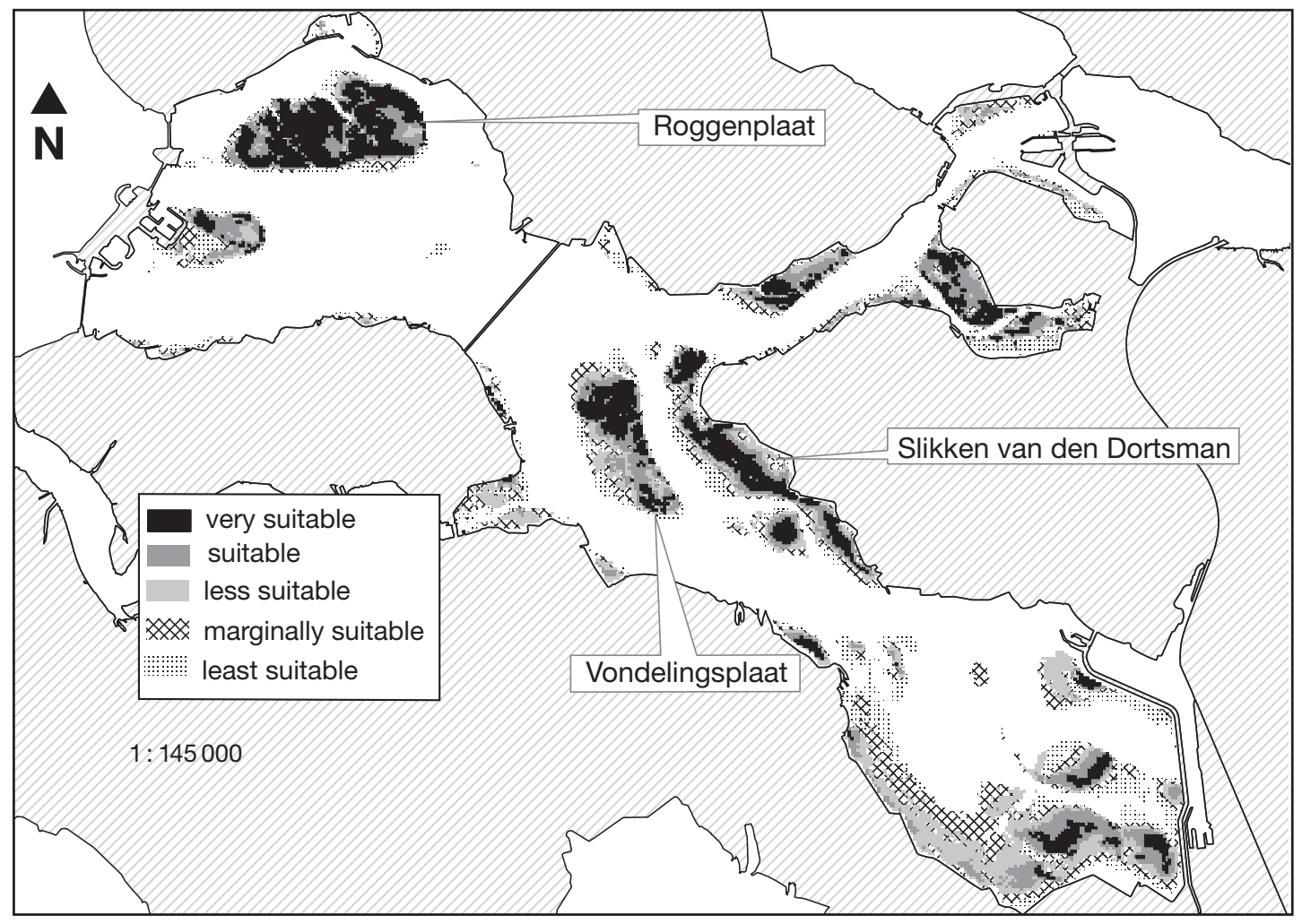

Fig. 3. Cockle habitat suitability map of the Eastern Scheldt

the oyster map of 2002, the highest percentage of grid cells occupied by Pacific oysters was found in areas classified as 'less suitable' for cockles (13\%). Oysters occupied fewer than $5 \%$ of the grid cells classified as 'very suitable' for cockles. The $\chi^{2}$ test for independence showed significant differences between the years $\left(\chi^{2}=\right.$ 17.5; $\mathrm{p}=0.002)$. Generally, Pacific oysters appear in cockle habitat areas classified as 'less suitable', 'marginally suitable' and 'least suitable', as shown in Fig. 4.

\section{DISCUSSION}

\section{Habitat model}

In this study a habitat model was developed to explain the distribution of cockle biomass in the Eastern Scheldt relative to salinity, current velocity and emersion time. Salinity (first and second order) and all interactions with salinity were non-significant. The fact that salinity does not play an important role is not surprising, given the limited salinity range in the Eastern Scheldt (28 to $33 \%$ ) and the relatively broad tolerance range of cockles (10 to $35 \%$ ).

Current velocity (first and second order) and emersion time (first and second order) explained $37.3 \%$ of the deviance. García-Charton \& Pérez-Ruzafa (2001) used Poisson regression to explain the species richness of reef fish in Spain. They found that $32.2 \%$ of species richness could be explained by the number of medium boulders and \% Posidonia fields, which is about the same as the deviance explained in this study. The estimated cockle stock approximates the measured cockle stock, which shows that the habitat model accurately reflects the actual stock.

\section{Current velocities}

In an experimental situation $\left(20^{\circ} \mathrm{C}\right)$, using a continuous flow, the Mediterranean mussel Mytilus galloprovencialis showed a maximum clearance rate at $25 \mathrm{~cm} \mathrm{~s}^{-1}$ (Denis et al. 1999). Filtration by blue mussels Mytilus edulis is inhibited by increasing the flow velocity from 6 to $25 \mathrm{~cm} \mathrm{~s}^{-1}$. Flows exceeding $25 \mathrm{~cm} \mathrm{~s}^{-1}$ cause much reduced consumption of chlorophyll a (Wildish \& Miyares 1990). Nevertheless, Widdows et al. (2002) found that the clearance rates of mussels from open coast sites were unaffected by current velocities up to $80 \mathrm{~cm} \mathrm{~s}^{-1}$.

Ysebaert et al. (2002) modelled the cockle population in the Western Scheldt. They predicted a probabi- 


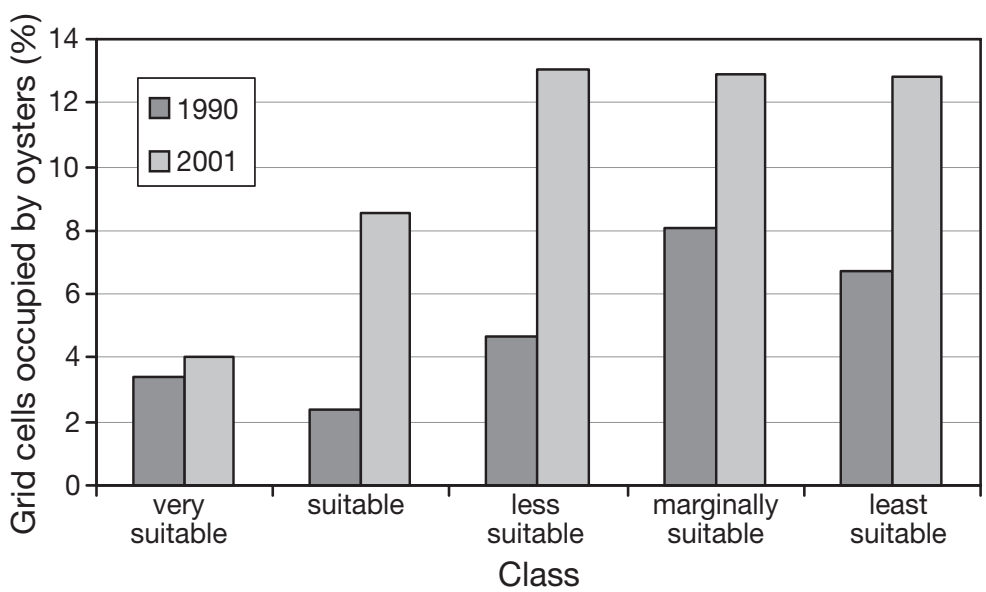

Fig. 4. Percentage of grid cells occupied by Pacific oysters in 1990 and 2001
$50 \%$ emersion time. In 1989 the highest biomass was found between -0.50 and $+0.25 \mathrm{~m}$, which is comparable to 35 to $55 \%$ emersion time. This means that, since 1985 at least, cockles in the Eastern Scheldt have been achieving their maximum biomass in areas with emersion times around 35 and $50 \%$.

The absence of high biomass at sites with low emersion times may be caused by predation pressure on the population at lower parts of the intertidal area. At high tide organisms like flounder, shrimp and crabs prey upon cockles (Richards et al. 1999), while at low tide birds like oystercatchers prey upon cockles in the same area (Meire et al. 1994b). Models of the Western

lity of $>10 \%$ that cockles would be found at maximum ebb current velocities between 10 and $60 \mathrm{~cm} \mathrm{~s}^{-1}$. This study shows that maximum biomass occurs at current velocities between 30 and $40 \mathrm{~cm} \mathrm{~s}^{-1}$, which is more or less in line with other studies. It should be noted that most studies present an average current speed, while this study used the maximum current velocity at ebb during spring tide.

\section{Emersion time}

The habitat model predicts maximum biomass at emersions between 40 and $60 \%$. At a study site in France, cockle growth was strongly influenced by habitat. Tidal elevation explained most of the observed differences in growth rate between experimental sites. Growth rates were reduced with emersion times over $50 \%$, and growth was expected to stop at emersion times over $70 \%$ (De Montaudouin 1996). De Montaudouin \& Bachelet (1996) also found in field experiments that individual growth rate and condition of cockles declined with increasing tidal elevation. These results are not in line with results found by the habitat model, because the model shows a preference for emersions around $50 \%$. This means that cockle biomass in the Eastern Scheldt behaves differently to the French study.

First, we need to establish whether this is a new situation, or if cockles have always had their highest biomass at emersion times around 40 to $60 \%$. Meire et al. (1994a) sampled macrozoobenthos in the Eastern Scheldt in 1985 and 1989, and took depth measurements of the sample points. Filter feeder biomass in this study consisted mainly of cockles. In 1985 the highest biomass was found in depth classes between -0.75 and $0 \mathrm{~m}$ below Amsterdam Ordnance Datum (NAP). This means they were found between 30 and
Scheldt produced by Ysebaert et al. (2002) showed that the probability of cockle occurrence increased with decreasing depth, which is comparable with an increase in emersion time. Bouma et al. (2001) showed that, on sand flats in the Western Scheldt where the sediment was unstable because of wave action, sediment dynamics and bed-level height were the variables that best explained the early recruitment patterns of cockles. Another possible explanation for the fact that cockles in the Eastern Scheldt are found in places with longer emersion times is that these places are too dynamic to be settled, as in the Western Scheldt.

If Pacific oysters completely took over the part of the habitat with emersion times below $30 \%$, this would lead to an influenced habitat preference of 40 to $60 \%$. However, Meire et al. (1994a) showed that cockle frequencies in the Eastern Scheldt have been high in the intertidal area since 1985. In 1985 the Pacific oyster had not yet established itself widely on intertidal sand flats (Kater \& Baars 2004). Therefore, Pacific oysters did not force cockles to move to higher zones in the intertidal area.

These results show that oysters do not occupy places were the map predicts high cockle biomass. This means there is no competition between oysters and cockles at most suitable cockle habitats, though there is competition at less suitable cockle habitats. Further expansion of oyster beds could lead to competition at most suitable cockle habitats in the future.

\section{Cockle fisheries}

The intertidal cockle habitat model presented here is composed of data collected over $10 \mathrm{yr}$. These data were collected in both fished and unfished areas. Due to significant differences between areas open to cockle 
fishing and areas where cockle fishing is not permitted, it was not possible to build 2 models and compare both habitats. To see whether cockle fisheries influence the present habitat map, one would need to know where cockles lived before cockle fishing started in the Eastern Scheldt. Unfortunately, no such data are available.

\section{CONCLUSIONS}

The distribution of cockles can be described using emersion time and current velocity. Salinity does not play any significant role. Response to current velocity is as expected, but response to emersion times (highest biomass at emersion times around 40 to $50 \%$ ) contradicts expectations based on other studies. This cannot be explained by competition from Pacific oysters. Possible explanations include high predation pressure around low water level, or instability of the sediment caused by waves preventing cockles from settling in this area. We recommend that the cause-effect relationships be explored further by means of experimental research.

Acknowledgements. This study was funded by the EVAII project commissioned by the Dutch Ministry of Agriculture, Nature and Food Quality. Thanks to C. van der Male and A. Schouwenaar for preparing the abiotic maps and B. J. Ens for comments on earlier versions of this manuscript. S. McDonnell is acknowledged for improving the English.

\section{LITERATURE CITED}

Banerjee N (2000) Script Create Map Theme Grid. Available at: http://arcscripts.esri.com

Bouma H, Duiker JMC, de Vries PP, Herman PMJ, Wolff WJ (2001) Spatial pattern of early recruitment of Macoma balthica (L.) and Cerastoderma edule (L.) in relation to sediment dysnamics on a highly dynamic intertidal sandflat. J Sea Res 45:79-93

Brock V (1980) The geographical distribution of Cerastoderma (Cardium) edule (L.) and C. lamarcki (Reeve) in the Baltic and adjacent seas related to salinity and salinity fluctuations. Ophelia 19(2):207-214

Coosen J, Twisk F, van der Tol MWM, Lambeck RHD, van Stralen MR, Meire PM, (1994) Variability in stock assessment of cockles (Cerastoderma edule L.) in the Oosterschelde (in 1980-1990), in relation to environmental factors. Hydrobiologia 282/283:381-395

Davies J (2000) Get Grid Value Extension. Available at: http://arcscripts.esri.com

De Montauduin X (1996) Factors involved in growth plasticity of cockles Cerastoderma edule (L), identified by field survey and transplant experiments. J Sea Res 36(3/4): 251-265

De Montaudouin X, Bachelet G (1996) Experimental evidence of complex interactions between biotic and abiotic factors in the dynamics of an intertidal population of the bivalve Cerastoderma edule. Oceanol Acta 19(3/4): $449-463$
Denis L, Alliot E, Grzebyk D (1999) Clearance rate responses of Mediterranean mussels, Mytilus galloprovincialis, to variation in the flow, water temperature, food quality and quantity. Aquat Living Resour 12(4) 279-288

Dijkema R (1997) Molluscan fisheries and culture in the Netherlands. In: MacKenzie Jr L, Burrel Jr VG, Rosenfield A, Hobart WL (eds) The history, present condition, and future of the molluscan fisheries of North and Central America and Europe. NOAA Technical Report NMFS 127

Drinkwaard AC (1999) Introductions and developments of oysters in the North Sea area: a review. Helgol Meeresunters 52:301-308

Eckman JE (1987) The role of hydrodynamics in recruitment, growth and survival of Argopecten irradians and Anomia simplex within eelgrass meadows. J Exp Mar Biol Ecol 106:165-191

Eckman JE, Peterson CH, Cahalan JA (1989) Effects of flow speed, turbulence and orientation on growth of juvenile bay scallops Argopecten irradians concentricus (Say). J Exp Mar Biol Ecol 132:123-140

Ens BJ (2003) What we know and what we should know about mollusc fisheries and aquacultures in the Wadden Sea. In: Wolff WJ, Essink K Kellerman A, van Leeuwe MA (eds) Proc 10th Int Sci Wadden Sea Symp, Ministerie van LNV, Den Haag

Ens BJ, Smaal AC, de Vlas J (2004) The effects of shellfish fishery on the ecosystems of the Dutch Wadden Sea and Oosterschelde. Final report on the second phase of the scientific evaluation of the Dutch shellfish fishery policy (EVA II). Alterra-rapport 1011, RIVO-rapport C056/04, RIKZ-rapport RKZ/2004.031. Alterra, Wageningen

García-Charton JA, Pérez-Ruzafa A (2001) Spatial pattern and the habitat structure of a Mediterranean rocky reef fish local assemblage. Mar Biol 138:917-934

Kamermans P, Smaal AC (2002) Mussel culture and cockle fisheries in the Netherlands: finding a balance between economy and ecology. J Shellfish Res 21:509-517

Kater BJ, Baars JMDD (2004) The potential of aerial photography for estimating surface areas of intertidal Pacific oyster beds (Crassostrea gigas). J Shellfish Res 23(3): 773-779

Kingston P (1974) Some observations on the effects of temperature and salinity upon the growth of Cardium edule and Cardium glaucum larvae in the laboratory. J Mar Biol Assoc UK 54:309-317

Meire PM, Seys J, Buijs J, Coosen J (1994a) Spatial and temporal patterns of intertidal macrobenthic populations in the Oosterschelde: are they influenced by the construction of the storm-surge barrier? Hydrobiologia 282/283: 157-182

Meire PM, Schekkerman H, Meininger P (1994b) Consumption of benthic invertebrates in the Oosterschelde estuary, SW Netherlands. Hydrobiologia 282/283:525-546

Piersma T, Koolhaas A, Dekinga A, Beukema JJ, Dekker R, Essink K (2001) Long-term indirect effects of mechanical cockle-dredging on intertidal bivalve stocks in the Wadden Sea. J Appl Ecol 38:976-990

Richards MG, Huxham M, Bryant A (1999) Predation: a causal mechanism for variability in intertidal bivalve populations. J Exp Mar Biol Ecol 241:159-177

Smaal A, van Stralen M, Schuiling E (2001) The interaction between shellfish culture and ecosystem processes. Can J Fish Aquat Sci 58:991-1002

Widdows J, Lucas JS, Brinsley MD, Salkeld PN, Staff FJ (2002) Investigation of the effects of current velocity on mussel feeding and mussel bed stability using an annular flume. Helgol Mar Res 56:3-12 
Wildish DJ, Kristmanson DD (1985) Control of suspension feeding bivalve production by current speed. Helgol Meeresunters 39:237-243

Wildish DJ, Miyares MP (1990) Filtration rate of blue mussels as a function of flow velocity: preliminary experiments. J Exp Mar Biol Ecol 142:213-219

Wildish DJ, Saulnier AM (1992) The effect of velocity and flow direction on the growth of juvenile and adult giant

Editorial responsibility: Otto Kinne (Editor-in-Chief), Oldendorf/Luhe, Germany scallops. J Exp Mar Biol Ecol 133:133-142

Wildish DJ, Kristmanson DD, Hoar RL, DeCoste AM, McCormick SD, White AW (1987) Giant scallop feeding and growth responses to flow. J Exp Mar Biol Ecol 113: 207-220

Ysebaert T, Meire P, Herman PJM, Verbeek H (2002) Macrobenthic species response surfaces along estuarine gradients: prediction by logistic regression. Mar Ecol Prog Ser 225:79-95

Submitted: July 15, 2005; Accepted: December 20, 2005

Proofs received from author(s): July 10, 2006 